\title{
分割造粒法を活用したマグネタイト鉱石の酸化促進による 焼結鉱強度および被還元性向上
}

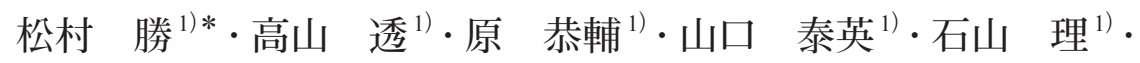 \\ 樋口 謙一 ${ }^{1)} \cdot$ 野村 誠治 $^{1)} \cdot$ 村上 $太$ (2) $^{2)}$ 林 幸 $^{3)} \cdot$ 大野 光一郎 $^{4)}$ \\ Improvement of Sinter Strength and Reducibility through Promotion of Magnetite Ore Oxidation \\ by Use of Separate Granulating Method \\ Masaru Matsumura, Toru Takayama, Kyosuke Hara, Yasuhide Yamaguchi, Osamu Ishiyama, \\ Kenichi Higuchi, Seiji Nomura, Taichi Murakami, Miyuki Hayashi and Ko-ichiro Ohno
}

Synopsis : In general, Fe content in iron ore is gradually decreasing. This fact affects worse performance of BF operation, for example, increase of RAR and Slag ratio. Depletion of high grade iron ore deposits is moving us to use concentrates in sintering process.

Through magnetite concentration deteriorates reducibility because of high $\mathrm{FeO}$ content in sinter product. Such situation makes it to promote oxidation of magnetite iron ore during sintering process for improving sinter reducibility. In addition, promoting oxidation of magnetite possibly increases sinter strength with using oxidation heat is exothermal reaction.

ISIJ sinter research group for utilization of magnetite concentration suggests that restricting melt formation is critical for promoting oxidation of magnetite concentration.

In this paper, It is confirmed that "Separate Granulation" has been examined to apply their suggestion by sinter pot test.

The main results obtained are described as follows:

(1) "Separate Granulation" in case that magnetite is pre-granulated with high $\mathrm{Al}_{2} \mathrm{O}_{3}$ iron ore without limestone and coke breeze resulted in decrease of $\mathrm{FeO}$ in sinter and improvement of both sinter reducibility and sinter strength.

(2) Sinter micro structure featured restriction of pore, low circle factor and small mineral texture, which supported that melting restriction worked during sintering.

(3) Magnetite decreased and hematite increased as sinter mineral, which corresponded with decrease of FeO content.

(4) These facts shown (1) to (3) concluded that "Separate Granulation" is effective to improve both sinter reducibility and sinter strength due to restriction of melting during sinter reaction.

Key words : sinter; magnetite; separate granulation; reducibility; sinter strength; concentration; iron ore.

\section{1. 緒言}

銑鉄製造に打いて, 焼結鉱は世界で最も多く使用されて いる高炉用鉄源である。日本では, その生産量は年間 8000 万トンを超え, その製造工程からの $\mathrm{CO}_{2}$ 排出量は国内総排 出量の約 $3 \%$ を占める。ここで, 焼結原料として使用される 鉄鉱石の鉄品位は徐々に低下しつつある。そのため, 鉄鉱 石山元であらかじめ選鉱処理し鉄分が濃化されたいわゆる Conc.が将来的に増加する。選鉱処理プロセスには，さま ざまな手法があるが，磁性を有する酸化鉄を磁力で選別す る方法が, 比重差を利用した浮遊選鉱と比較して容易であ る。磁性を有する鉄鉱石は，一般的にマグネタイト $\left(\mathrm{Fe}_{3} \mathrm{O}_{4}\right)$
であるので，まずはこれに着目した使用技術確立を目指 す。従来，マグネタイト鉱石多配合すると，焼結鉱中の $\mathrm{Fe}^{2+}$ が増加し被還元性が悪化すること ${ }^{1)}$ が知られている。従っ て, 焼結過程に打いてマグネタイトのへマタイトへの酸化 促進が重要である。酸化促進は上記効果の他, 生成熱量増 を享受できるため, 焼結鉱の強度を改善できる。よって, 従来は焼結用熱源を操作因子とした場合には相反因子とさ れる焼結鉱の強度と被還元性の両立を, マグネタイト鉱石 の酸化促進により達成する可能性が高い。

上記背景に基づいて，マグネタイトの酸化促進による日 本本鉄鋼協会研究会「資源対応型高品質焼結鉱製造プロセ 不研究会」拈いて, 大学側の研究に扔いて, 下記知見が得

平成28年 8 月9日受付 平成28年11月21日受理 (Received on Aug. 9, 2016; Accepted on Nov. 21, 2016)

1）新日鐵住金 (株) 技術開発本部（Technical Research\&Development Bureau, Nippon Steel \& Sumitomo Metal Corporation, 20-1 Shintomi Futtsu Chiba 293-8511)

2) 東北大学大学院環境科学研究科 (Graduate School of Environmental Studies, Tohoku University)

3）東京工業大学物質理工学院 (Department of Metallurgy and Ceramics Science, Tokyo Institute of Technology)

4) 九州大学大学院工学研究院 (Department of Material Science and Engineering, Kyushu University)

* Corresponding author : E-mail : matsumura.7fh.masaru@jp.nssmc.com

DOI : http://dx.doi.org/10.2355/tetsutohagane.TETSU-2016-082 
られた。

1) マグネタイト鉱石の酸化促進のためには, 鉱石近傍の 酸素ポテンシャルを高めて液相生成を抑制する ${ }^{2)}$ 。こ れを達成するには, マグネタイトはフラックス $(\mathrm{CaO}$ 源）打よび炭素系凝結材 (粉コークス等) から遠隔配 置する。

2) 大気雲囲気下抏いて試薬へマタイトと比較して試薬 マグネタイトは $\mathrm{CaO}$ との反応による液相生成温度が 低い ${ }^{3)}$ 。よって, 上記1）記載の液相生成抑制のために は, マグネタイトはフラックス $(\mathrm{CaO}$ 源 $)$ から遠隔配 置する。

3) $\mathrm{FeOx}-\mathrm{CaO}-\mathrm{SiO}_{2}$ 系状態図の $\mathrm{FeOx}$ 飽和領域において, $\mathrm{Al}_{2} \mathrm{O}_{3}$ 添加は液相比を低下せしめる ${ }^{4)}$ 。よって液相生 成抑制には, $\mathrm{Al}_{2} \mathrm{O}_{3}$ 濃度上昇が有効である。

遠隔・近接手段として, 二種造粒物の作り込み可能な, 二系列で造粒する分割造粒 ${ }^{5)}$ ，打よび二層構造の造粒物の 作り込久可能な, 一部の原料を別系統で造粒し合流後再造 粒する選択造粒 ${ }^{6}$ の活用が有効である。本研究では, より 遠隔配置が可能な分割造粒 ${ }^{5}$ を採用し，マグネタイト鉱石 の酸化促進を介した被還元性および泠間強度の向上を，60 $\mathrm{kg}$ 規模の焼結鍋試験で評価した。

\section{2. マグネタイト酸化促進に関する ISIJ 研究会基礎的知見}

まず，緒言で述べた「資源対応型高品質焼結鉱製造プロ セス研究会」におけるマグネタイトの酸化挙動に及ぼす液 相生成の影響に関する基礎的知見を本章で総括する。

マグネタイトの酸化促進において, 液相生成との関連を 評価することは, 焼結プロセス上重要である。ここで, 液 相生成の関連とは, マグネタイト酸化と液相生成との時系 列的順序の適正化である。液相がマグネタイト鉱石表層を 濡らして, 酸素との接触を妨害するのであれば, 液相生成 前の昇温段階でへマタイトまで酸化させておく必要があ る。一方, 液相生成により粒子内部の未酸化領域を順次露 出させて酸化していくのであれば, 液相生成と酸化反応は 同時進行させる必要がある。さらに，第三として，マグネ タイトとフラックスとを積極的に反応させ，液相を生成せ しめた後に, 液相段階または冷却過程の固相析出段階で酸 化させるのであれば，マグネタイト酸化以前に積極的に液 相生成させるべきである。

Fujino $\check{ら}^{2)}$ は, アルミナ球充填層中にグリーンボール (直 径 1-2 mm）を配置し, 空気流通下で酸化反応挙動を調査し た。その結果，Fig.1に示すように, $900^{\circ} \mathrm{C}$ 空気流通下にお いて, マグネタイト微粉と共に $\mathrm{CaO}$ を $20 \mathrm{mass} \%$ 添加した グリーンボールは，マグネタイト微粉だけのグリーンボー ルと比較して, 酸化率が低下した。 $\mathrm{CaO}$ 添加したグリーン ボールの泠却後の組織観察結果より, グリーンボールの内
部に未酸化のマグネタイトが確認されており, グリーン ボール表層には，カルシウムフェライト系鉱物が生成して おり高温下に打ける液相の存在を示唆する。よって, 生成 した液相が空気を遮断して特にグリーンボール内部のマグ ネタイト酸化を抑制したものと考えられる。また, 結果は 揭載しないが，マグネタイ微粉グリーンボールとコークス 粒子を混合配置するとグリーンボール単味と比較して酸化 率が低くなった。これは,コークス燃焼ガスの酸素ポテン シャルが低いため，またはコークスとの固相反応により， へマタイト生成が抑制されると考察している。さらに，マ グネタイト微粉鉱と微粉コークスの混合物をマグネタイ 卜安定雲囲気下で昇温した際の重量変化を測定した。その 結果, Fig.2に示す通り, $400^{\circ} \mathrm{C}$ 以上で重量増加し $700^{\circ} \mathrm{C}$ 以上 で重量減少した。 $400^{\circ} \mathrm{C}$ 以上の重量増加はマグネタイトの 酸化反応, $700^{\circ} \mathrm{C}$ 以上の重量減少は粉コークスの酸化 (燃 焼) と一部のマグネタイト微粉鉱の還元反応と考えられる。 従って, マグネタイトは $400^{\circ} \mathrm{C}$ 以上で酸化可能であり, 粉 コークス燃焼までに可能な限り酸化促進させておくことが

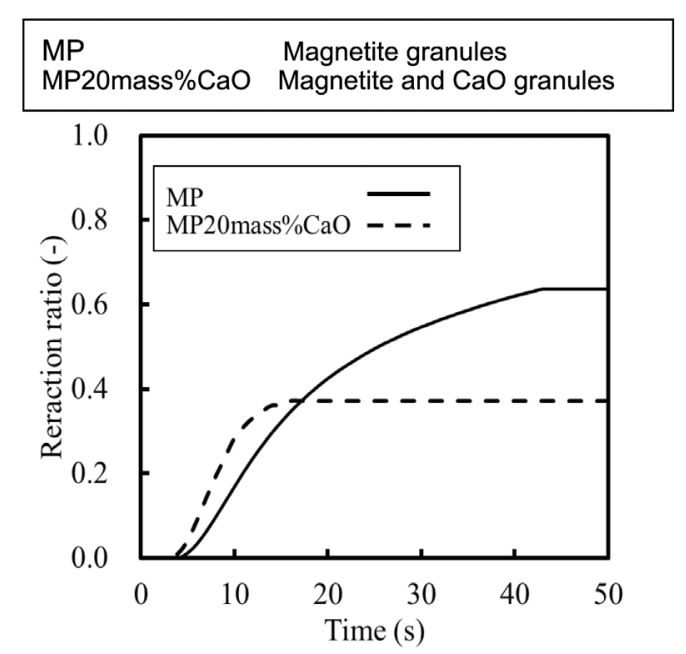

Fig. 1. Change in reaction ratio of green ball of magnetite concentrate with and without $\mathrm{CaO}^{2)}$.

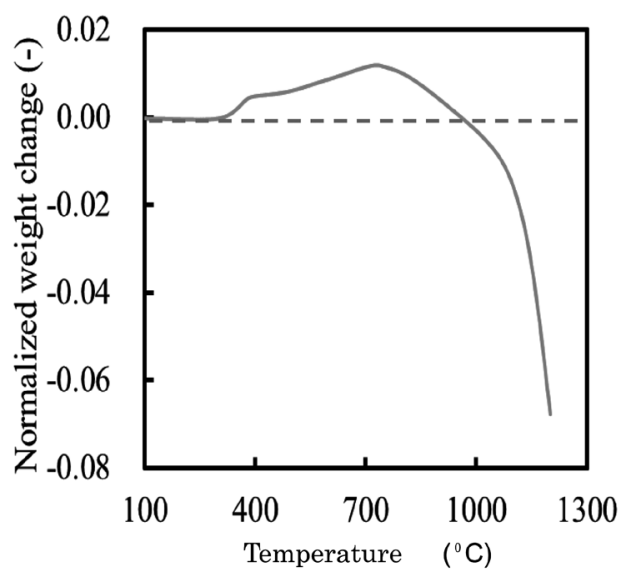

Fig. 2. Normalized weight change of magnetite concentrate and coke breeze with temperature ${ }^{2}$. 
重要である。さらに粉コークスと遠隔配置することで, 低 酸素ポテンシャルガスや直接反応によるマグネタイト酸化 抑制が回避できる。

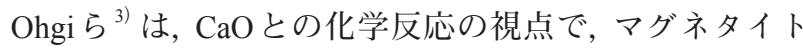
試薬とへマタイト試薬を比較した。

Fig.3に示す通り, 空気気流中に扔いては, マグネタイト 一 $\mathrm{CaO}$ 間で形成する鉱物は, $4 \mathrm{CaO} \cdot \mathrm{FeO} \cdot 8 \mathrm{Fe}_{2} \mathrm{O}_{3}$ 打よび $3 \mathrm{CaO} \cdot \mathrm{FeO} \cdot 7 \mathrm{Fe}_{2} \mathrm{O}_{3}$ で，いずれも $1200^{\circ} \mathrm{C}$ 以下で溶融する。 従って, ヘマタイトと比較してマグネタイトは, $\mathrm{CaO}$ との 反応により，より低温で液相を生成する結論に至った。

Hayashi $ら^{4)}$ は, $\mathrm{FeOx}-\mathrm{CaO}-\mathrm{SiO}_{2}-\mathrm{Al}_{2} \mathrm{O}_{3}$ 系平衡状態図に おける $\mathrm{FeOx}$ 飽和領域における液相線上の組成を分析し た。その結果, Fig.4に示す通り, $\mathrm{Al}_{2} \mathrm{O}_{3}$ 濃度上昇とともに, $\mathrm{FeOx}$ 濃度が低下した。 $\mathrm{FeOx}$ 濃度低下は，三成分系状態図 の $\mathrm{FeOx}$ 頂点から液相線への距離が増加することと同義で ある。これは, $\mathrm{FeOx}$ 飽和領域において液相領域が縮小する こと，すなわち，同一温度では，液相率が低下することを 意味する。工業的には，マグネタイト鉱石近傍に高 $\mathrm{Al}_{2} \mathrm{O}_{3}$ 鉱

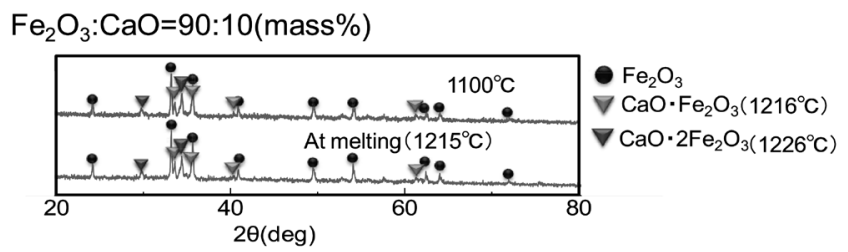

$\mathrm{Fe}_{3} \mathrm{O}_{4}: \mathrm{CaO}=90: 10$ (mass $\%$ )

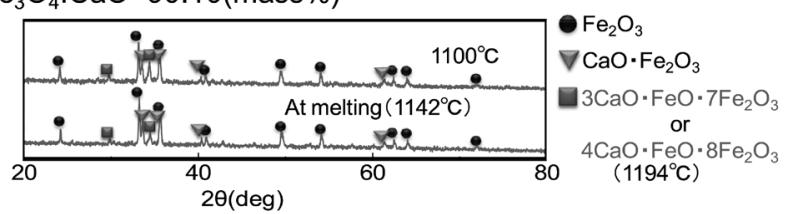

Fig. 3. Mineral phase of quenched sample and melting temperature during increasing temperature under reaction with $\mathrm{CaO}$ component ${ }^{3)}$.

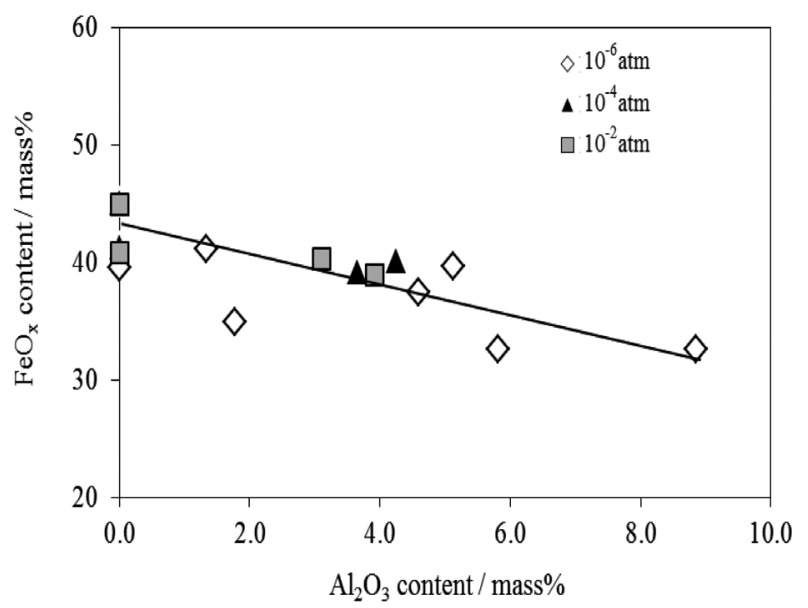

Fig. 4. Influence of $\mathrm{Al}_{2} \mathrm{O}_{3}$ content on equivalent $\mathrm{FeOx}$ content on liquidas composition at $\mathrm{FeOx}-\mathrm{SIO}_{2}-\mathrm{CaO}-\mathrm{Al}_{2} \mathrm{O}_{3}$ Phase diagram $^{4}$.
石配置が，マグネタイト溶融抑制において重要であること を示唆する。焼結プロセスに打ける $\mathrm{Al}_{2} \mathrm{O}_{3}$ 成分の液相生成 に及ぼす影響については, 溶融抑制の報告 ${ }^{7-10)}$ が多く, 本 知見 ${ }^{4)}$ は，これら過去知見を基礎的に傍証した。

以上の研究会基礎知見 ${ }^{2-4)}$ を踏まえると, 焼結操業への 指針として, 焼結原料層に扔いて溶融までのマグネタイト の酸化促進にはマグネタイトを $\mathrm{CaO}$ と近接させず, 高酸素 ポテンシャル維持のため, 粉コークスとも近接させないこ とが重要である。さらに, 液相生成抑制のため, マグネタ イト鉱石へ $\mathrm{Al}_{2} \mathrm{O}_{3}$ 含有率の高い鉄鉱石を近接させることが 有効である結論にいたった。

近接・遠隔の手段として, マグネタイト鉱石に対する遠 隔・近接原料設計を実焼結プロセスに打いて実施するには， 二系列で造粒する “分割造粒法”) の採用が有効である。即 ち, 焼結原料を2系統に分割し、マグネタイト鉱石を主体 とする系統とフラックス・粉コークスを主体とする系統と をそれぞれ造粒したのちに配合して焼結する。次章以降に 本手法の効果について評価する。

\section{3. 実験方法}

\section{$3 \cdot 1$ 鍋試験方法}

Table 1 に焼結原料配合条件打よび焼結鉱べースの成分 を示す。鉄鉱石については，マグネタイトConc.の他，日 本で使用されている主要鉄鉱石 4 種類を用いた。粉コー クス配合比率は 4.5 mass\%〜 6.0 mass\%の範囲で変更した。

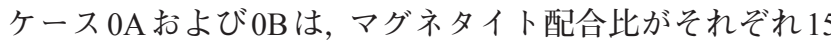
mass\%および0 mass\%で，双方ともに全原料一括造粒を採 用した。一方，ケース1打よびケース 2 は，マグネタイト 鉱石 $15 \mathrm{mass} \%$ 配合に打いて，原料を二系統に分けて別々 に造粒する分割造粒を採用した。ケース 1 においては，マ グネタイト鉱石を配合する予備造粒（Table 1 表記の Sep.) には, ヘマタイト D鉱石の他, $\mathrm{CaO}$ 源としては造粒に必要 な最小限の生石灰のみ配合し，本造粒（Table 1 表記上の Main）には残りの原料を配合したが，大部分の $\mathrm{CaO}$ 源（生

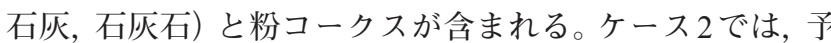
備造粒（Table 1表記の Sep.) に配合したへマタイトD鉱石 の代わりに高 $\mathrm{Al}_{2} \mathrm{O}_{3}$ ゲーサイト Bを配合した。即ち, ケー ス 1 ではマグネタイト鉱石を $\mathrm{CaO}$ 源打よび粉コークスと遠 隔配置し，ケース2ではさらにマグネタイト鉱石と高 $\mathrm{Al}_{2} \mathrm{O}_{3}$ 鉱石を近接配置した。

造粒方法については，一括造粒打よび分割造粒の本造粒 （Table 1表記上の Main）については，ドラムミキサー（直 径 $600 \mathrm{~mm}$ 長さ $800 \mathrm{~mm}$ ) で4分間混合後，水分を添加しさ らに 4 分間造粒した。一方，分割造粒の予備造粒（Table 1 表記のSep.）については，高速覮拌ミキサーで1分間処理 し, 水分添加後, 再度 1 分間処理し, パンペレタイザー (パ ン径 $800 \mathrm{~mm}$ 深さ $200 \mathrm{~mm}$ ) で5 分間処理した。 
焼結鍋は直径 $300 \mathrm{~mm}$ 高さ $500 \mathrm{~mm}$ であり，同一直径の 風箱上に固定した。原料装入後，熱電対を鍋上面より\& $240 \mathrm{~mm}$ および $430 \mathrm{~mm}$ の高さの位置の垂直断面円中央部に セットした。なお，風箱中央部にも熱電対をセットした。

点火は風箱内圧力ー $5.2 \mathrm{kPa}$ で吸引しながら LPG を燃料 とするバーナーで1 分間燃焼させた。点火後は風箱内圧力 - $10.3 \mathrm{kPa}$ 一定で行った。風箱内圧力は, 風箱から送風機 間のダクトに設置したダンパー開度で調整した。風箱内中 央部に設置した熱電対で排ガス温度を計測し, 焼結時間は 排ガス温度ピーク時刻までの時間と定義した。点火終了 から焼結終了まで, 排ガスの一部を連続採取し, 除湿除塵 処理した後に, $\mathrm{CO}, \mathrm{CO}_{2}$ および $\mathrm{O}_{2}$ を分析した。 $\mathrm{CO}$ おび $\mathrm{CO}_{2}$ は赤外吸収法, $\mathrm{O}_{2}$ は磁化法による方法で，ポータブル 分析計を用いた。焼成中の通気性は，排ガスダクトに設置 した流速計より風量を連続測定して, 焼結原料層を流通す るガス流量とした。

焼結鍋から排出した焼結ケーキは, 重量計測後に落差2.0 $\mathrm{m}$ で 4 回落下させ $5 \mathrm{~mm}$ で篩分けし, 成品焼結鉱を得た。

\section{$3 \cdot 2$ 焼結鉱品質指標}

成品焼結鉱を笠分けし，大塊は破砕・整粒して，10-40 mm $15 \mathrm{~kg}$ を 200 回転処理し, $+6 \mathrm{~mm}$ 比率で冷間強度とし た。一方 19-21 mm試料500 g を旧JIS法に基づいた RI 試験 を行い，その指標を被還元性とした。

\section{3 光学顕微鏡断面観察および画像解析による気孔評価}

焼結鉱 15-19 mm 樹脂へ埋込・切断して2 次元断面の
気孔を観察した。画像解析法 ${ }^{11)}$ に断面中の気孔数をカウン トした。

気孔毎に気孔面積を計測して, 等面積の円相当径を算出 した。円相当径の度数分布で気孔の微細化を評価した。一 方, 気孔毎に周長を測定し周囲長 $\mathrm{A}$ と定義し, 等面積の円 相当直径を周囲長 $\mathrm{B}$ と定義して, 円形度 $=$ 周囲長 $\mathrm{B} /$ 周囲 長 $\mathrm{A}$ を求めた。円形度は四凸度の指標であり, 液相生成下 では，気孔が丸みを帯びるため，円形度が上昇する。一方， 液相が生成しない場合，焼成前の気孔形状が維持されるた め，一般的には円形度が小さくなる。

\section{$3 \cdot 4$ 粉末X線回折による鉱物同定}

焼結鉱 $15-19 \mathrm{~mm}$ を粉砕し粒度を数 $10 \mu \mathrm{m}$ 以下にした。こ れを，ディフラクトメーター法によりXRD測定を実施し た ( $\mathrm{X}$ 線源 : $\mathrm{CuK} \alpha$, 検出器 : シンチレーションカウンタ)。 $\mathrm{X}$ 線光学系は集中法を用い, 測定法は2 2 - $\theta$ スキャンで測定 した。リートベルト解析を行うには，できる限り広い $2 \theta$ 範 囲の $\mathrm{S} / \mathrm{N}$ 比の高いデータが必要である。そこで $2 \theta$ の範囲 をある一定間隔刻み $(\Delta 2 \theta)$ で動かし，指定した時間の回 折ピークを検出するステップスキャンという手法で測定 を行った。年の際の測定条件は, $2 \theta=10 \sim 120^{\circ}, \Delta 2 \theta=$ $0.04^{\circ}$, 露光時間 $20 \mathrm{~s}$ である。

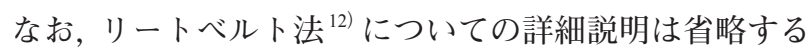
が, 粉末回折パターン全体に含まれている情報を最大限に 抽出するため, 実測パターンとできるだけよく一致するよ うに近似構造モデルに基づいて計算した回折パターンを最

Table 1. Blending condition and calculated chemical composition.

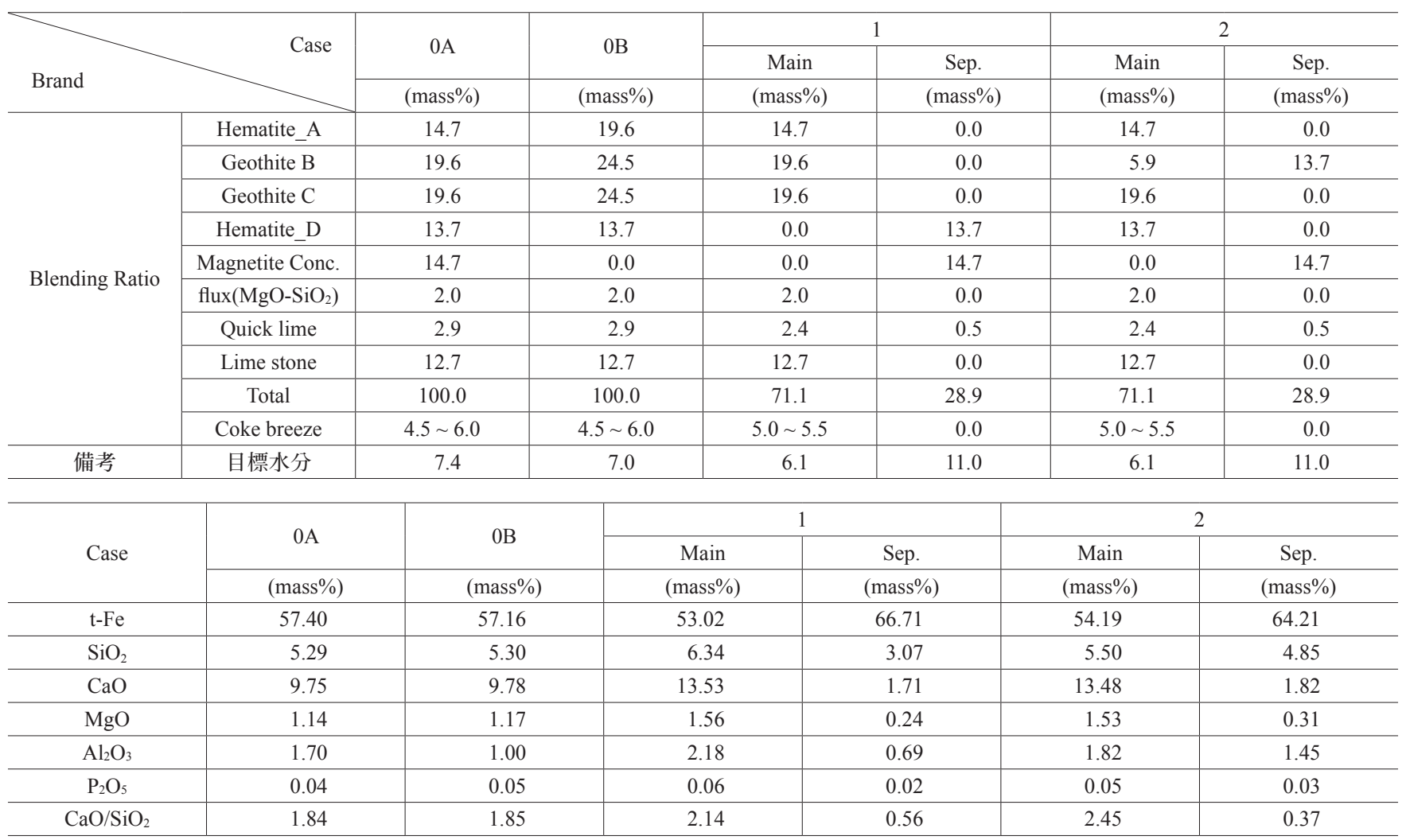


適化する手法である。

\section{4. 実験結果}

\section{$4 \cdot 1$ 焼結鉱被還元性および冷間強度}

Fig.5に, 粉コークス配合比と焼結鉱 $\mathrm{FeO}$ 濃度との関係を 示す。一括造粒ケース $(0 \mathrm{~A}, 0 \mathrm{~B})$ ともに，粉コークス配合 比の上昇と共に, $\mathrm{FeO}$ が上昇する。ケース $0 \mathrm{~A} と 0 \mathrm{~B}$ を比較 すると，マグネタイト配合比の高いケース $0 \mathrm{~A} の$ 方が $\mathrm{FeO}$ は高く，配合したマグネタイトがへマタイトまですべては 酸化していないことを意味する。ケース $0 \mathrm{~A}$ とマグネタイ 卜配合比が等しく分割造粒を採用したケース 1 およびケー ス 2 は, $\mathrm{FeO}$ 值が低い。粉コークス配合比 5.5 mass\%条件同 士で比較すると，ケース1打よびケース 2 は，マグネタイ 卜配合比 0 mass $\%$ のケース $0 \mathrm{~B}$ と同等の $\mathrm{FeO}$ 值であった。即 ち，本研究の技術思想に基いた配合条件での分割造粒を採 用すると，マグネタイトの酸化が促進される結果が得られ た。

Fig.6 打よびFig.7に，粉コークス配合と被還元性（RI）お よび冷間強度（TI）との関係を示す。マグネタイトを配合 し一括造粒ケースである $0 \mathrm{~A} の$ 傾向をみると, 粉コークス

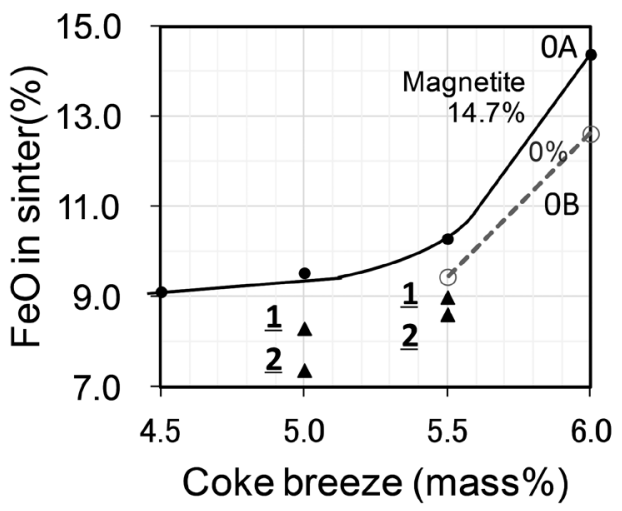

Fig. 5. Influence of coke breeze ratio and granulation method on $\mathrm{FeO}$ in sinter.

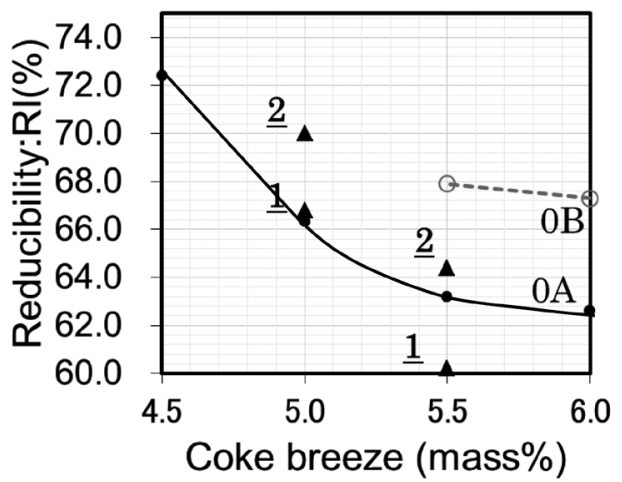

Fig. 6. Influence of coke breeze ratio and granulation method on reducibility.
配合量上昇と共に, 被還元性が低下し冷間強度が上昇す る。

さらに一括造粒でのマグネタイト鉱石配合比 0 mass $\%$ 配合のケース $0 \mathrm{~B} は ， ケ ー ス 0 \mathrm{~A}$ と比較して被還元性が高く 冷間冷間強度が等しい。これは，マグネタイト配合による $\mathrm{FeO}$ 増が被還元性を悪化せしめるが, マグネタイトの酸化 熱も少ないため, 冷間強度は向上しないことを意味する。

粉コークス配合比 5.5 mass\%のケース 1 を除いて, マグ ネタイト配合下で分割造粒法を採用すると被還元性および 冷間強度の双方が向上した。これは，マグネタイト酸化促 進により, 焼結鉱 $\mathrm{FeO}$ 濃度が低下して被還元性が向上する と共に, 酸化熱量上昇による焼結過程における熱量上昇を 介した泠間強度向上である。

Fig.8に, 粉コークス配合比 5.0 mass\%に打けるマグネ タイト配合条件であるケース $0 \mathrm{~A} ， 1 ， 2$, に打ける充填層上 面から $100 \mathrm{~mm}$ 位置および $250 \mathrm{~mm}$ 位置におけるヒートパ ターンを示す。Fig.8において上段が $100 \mathrm{~mm}$ 位置下段が $250 \mathrm{~mm}$ 位置である。なお，上段下段共に，右側が左側の $1000^{\circ} \mathrm{C}$ 以上を拡大した図面である。一括造粒と比較して分 割造粒のケースは, 最高到達温度の差異は小さかったが $1200^{\circ} \mathrm{C}$ 以上の高温保持時間が伸延した。

\section{4 -2 光学顕微鏡断面観察および画像解析による気孔評価}

Fig.9に, 粉コークス配合比 5.0 mass\% $\%$ でマグネタイト鉱 石を 15 mass\%配合条件に打ける分割造粒 (Case2) および 一括造粒 (Case $0 \mathrm{~A})$ の焼結鉱断面の組織を比較する。まず, 気孔の点では, 分割造粒のケースでは, $100 \mu \mathrm{m}$ 以下の気孔 が多く存在していたが, 一括造粒のケースでは, $50 \mu \mathrm{m}$ 前 後の気孔が多く $100 \mu \mathrm{m}$ 以上の気孔も2られる。さらに気 孔も丸みを帯びているため, 溶融を介して気孔統合が促進 したものと推察する。次に, 鉱物の点では, 分割造粒のケー スでは, 斑状へマタイトが多く存在していたが, 一括造粒 のケースでは, 骸晶状へマタイトが多くみられる。一般的 に, 骸晶状へマタイトは液相から析出し斑状へマタイトは 固相から析出する。斑状へマタイトは液相生成源である石 灰石から遠隔配置されているマグネタイト微粉と高 $\mathrm{Al}_{2} \mathrm{O}_{3}$

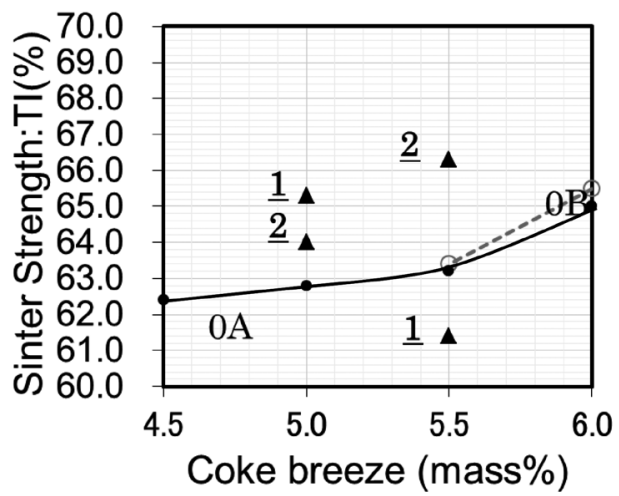

Fig. 7. Influence of coke breeze ratio and granulation method on sinter strength. 
ゲーサイト鉱石由来と考えられる。即ち，マグネタイトが 酸化して斑状へマタイトへ変化したものと考えられる。

以上, 気孔打よび鉱物の特徵より，一括造粒のケースは 分割造粒のケースと比較して, 焼結過程において多量の液 相を生じていたと考えられる。

Fig.10に，粉コークス配合比 5.0 mass\% でマグネタイト 鉱石を 15 mass\%配合条件における分割造粒 (Case2) およ び一括造粒 (Case $0 \mathrm{~A})$ の円相当径分布を示す。なお，各ケー スサンプル2個ずつ供した。分割造粒を採用したケース 2 および一括造粒を採用したケース $0 \mathrm{~A}$ は，それぞれ円相当

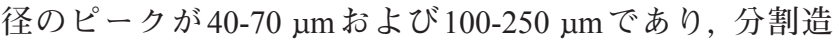
粒のケースの方が円相当径が小さい。また, 円相当径での 積分值が気孔量を意味するが, 分割造粒のケースは気孔量 が多い。

Fig.11に，円形度分布を示す。分割造粒のケースでは，円 形度 $0.5 \sim 0.8$ の気孔が多い。一方，一括造粒のケースでは, 円形度 0.8 未満の気孔が少なく 0.8 以上の気孔が大半を示 す。

以上, Fig.9-11より, 一括造粒のケースと比較して分割造 粒のケースは, 溶融抑制により骸晶状へマタイト減少, 気
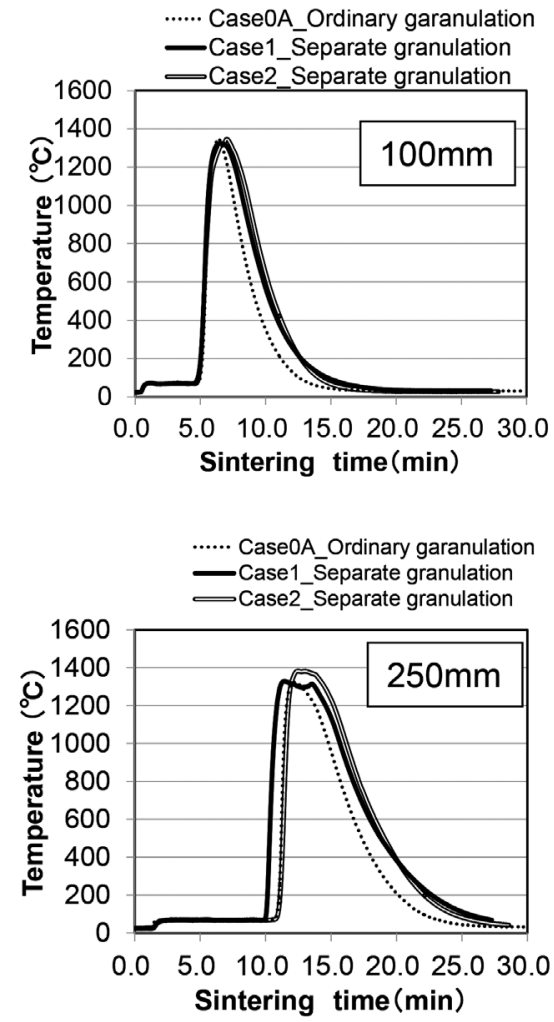
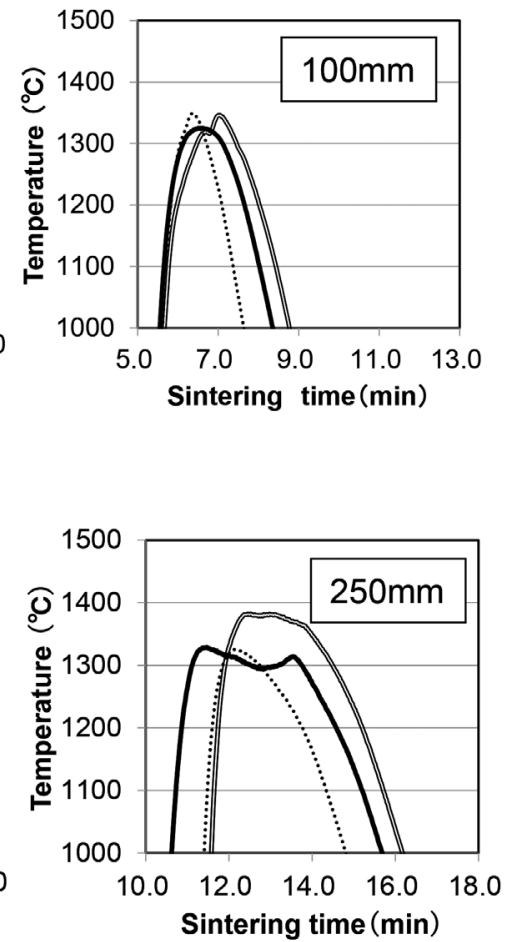

Fig. 8. Increasing high temperature $\left(>1200^{\circ} \mathrm{C}\right)$ holding time by use of separating granulation method.

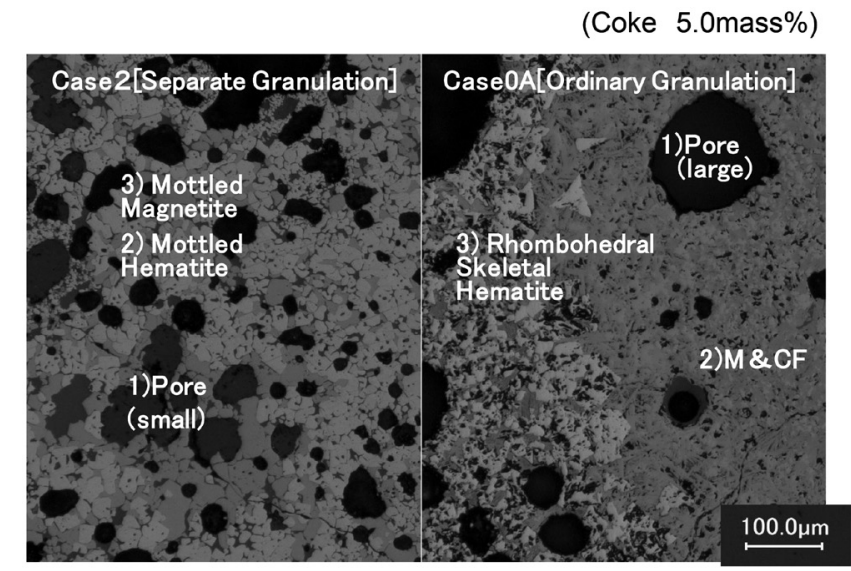

Fig. 9. Comparison of microscope image between at ordinary granulation and at separate granulation under blending magnetite fine.
(Coke 5.0mass \%)

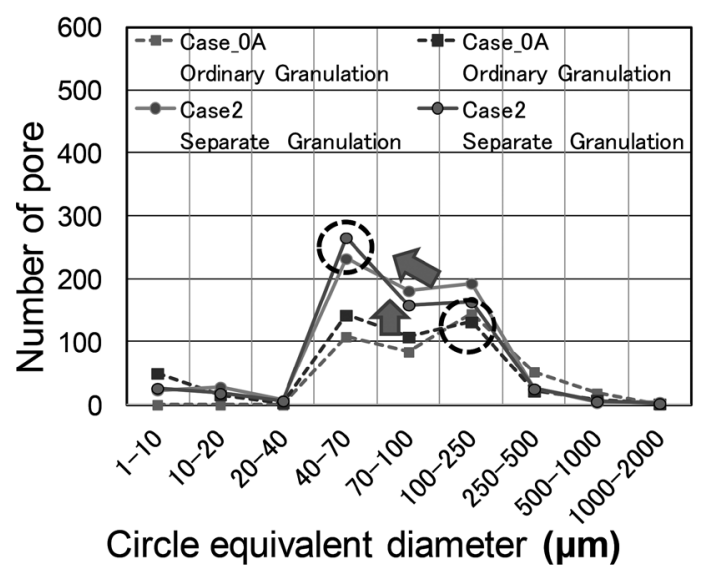

Fig. 10. Increasing number of pore and decreasing pore size by use of separate granulation method. 
孔統合の抑制，気孔円形度低下に結びついたと考える。こ こで, 気孔統合の抑制や気孔円形度减少は，還元反応促進 にとって有利である。

\section{$4 \cdot 3$ 粉末X線回折による鉱物同定}

Fig.12に，リートベルト解析に基づいて得られた鉱物定 量結果を示す。分割造粒のケースは，一括造粒のケースと 比較して, ヘマタイトが上昇しマグネタイトが減少した。 つまり，分割造粒による $\mathrm{Fe}^{2+}$ から $\mathrm{Fe}^{3+}$ への酸化が促進され た。SFCA（多成分カルシウムフェライト）およびシリケー 卜系鉱物については，造粒方法の相違による差異が小さ かった。

\section{5. 考察}

\section{$5 \cdot 1$ 消費熱量の考元方}

マグネタイト酸化熱等の生成熱量変化が焼結鉱の冷間強 度と被還元性の双方に関与した。ここでは, 焼結層熱量に ついて, 焼結層生成熱量と焼結層を流通するガス顕熱を入 出考慮した焼結層内消費熱量として層高別に定量評価し

(Coke 5.0mass\%)

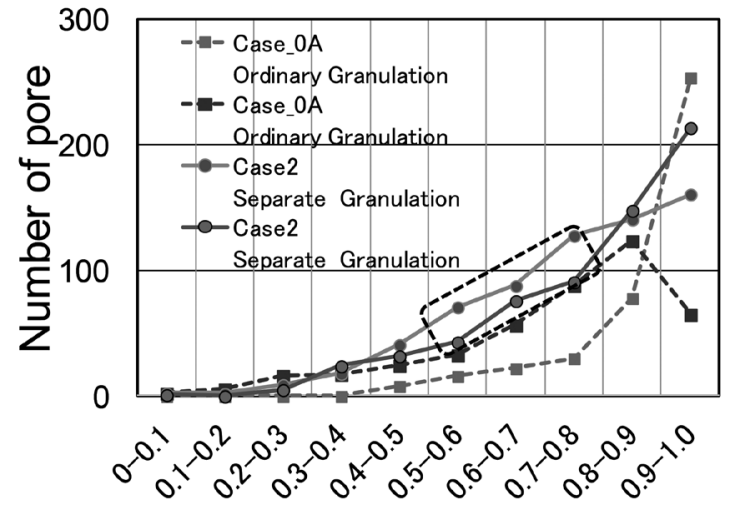

Circle factor(-)

Fig. 11. Decreasing pore circle factor by use of separate granulation method.

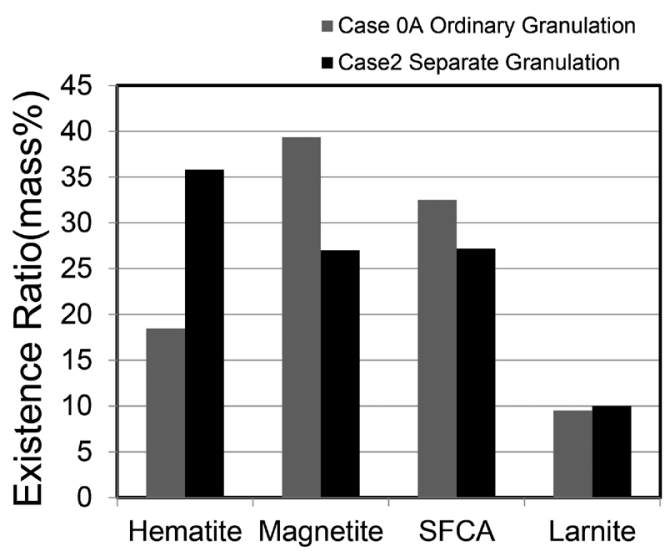

Fig. 12. Influence of granulation method on mineral constitution.
た。Fig.13に，その考え方を示す。焼結層内を3層に分割し て, 焼結層消費熱量を, 入熱量十生成熱量一出熱量で算出 した。ここで，入熱量および出熱量は，上中下層それぞれ 該当する焼結層上面および下面に設置された熱電対で計測 される温度をガス温度として, 風量およびガス比熱を乗じ 時間積分した。積分時間帯は，燃焼前線が3層それぞれの 領域に存在する時間帯とした。燃焼前線到達時刻は, 熱電 対温度 $70^{\circ} \mathrm{C}$ に到達した時刻とした。

\section{$5 \cdot 2$ 焼結層生成熱量}

焼結層生成熱量は粉コークスに燃焼効率を考慮した燃焼 熱打よびマグネタイトからへマタイトへの酸化熱である。 燃焼効率は風量および排ガス組成 $\left(\mathrm{CO}, \mathrm{CO}_{2}, \mathrm{O}_{2}\right)$ に基づい て算出した。Fig.14に，焼結層入側および出側のガス量お よびその組成の概略を示す。ガス組成については, $\mathrm{H}_{2} \mathrm{O} の$ 他, 数百 ppm と微量な $\mathrm{SOx}, \mathrm{NOx}$ 無視し, $\mathrm{CO}, \mathrm{CO}_{2}, \mathrm{O}_{2}$, $\mathrm{N}_{2}$ の 4 成分でバランス計算した。入側ガス組成は $\mathrm{O}_{2}$ 濃度 $21 \%, \mathrm{~N}_{2}$ 濃度 $79 \%$ とした。出側の $\mathrm{N}_{2}$ 濃度は $\mathrm{CO}, \mathrm{CO}_{2}, \mathrm{O}_{2}$ 濃 度の和を $100 \%$ から引いて求まる。この出側 $\mathrm{N}_{2}$ 濃度より, 入側ガスと出側ガスとの量比が定まる。そして, 出側ガス

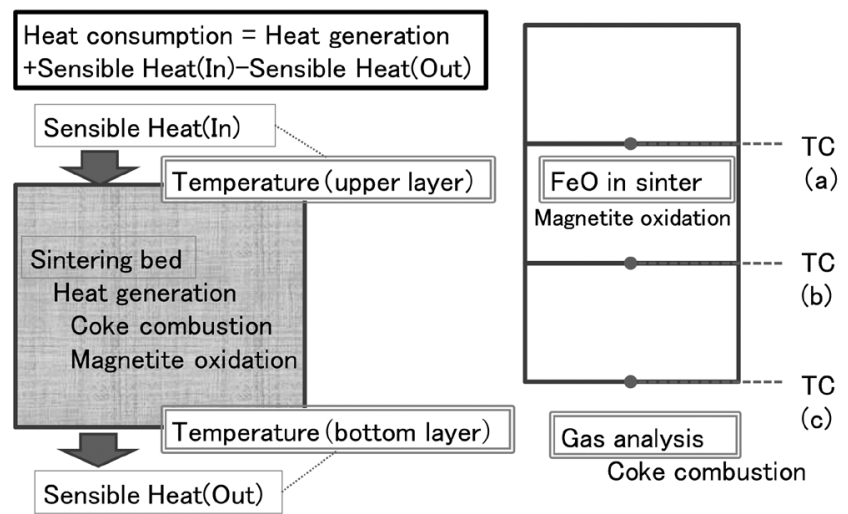

Fig. 13. Concept of heat generation in sintering bed.

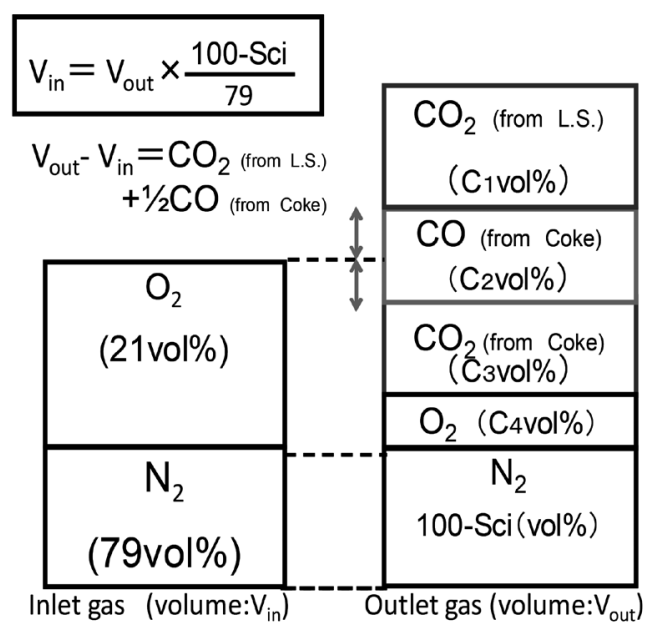

Fig. 14. Volume balance between inlet and outlet gas. 
量は入側ガス量よりも多く, 学の差分は, 石灰石等炭酸物 から生成する $\mathrm{CO}_{2}$ 量打よびコークス燃焼で生じる $\mathrm{CO}$ の半 量である。前者は酸素ガスを消費しない固体からの脱離ガ スのため, 後者は 1 モルの酸素分子から 2 モルの $\mathrm{CO}$ が生成 するためである。そして, 炭酸物から生成する $\mathrm{CO}_{2}$ が求ま れば，コークス燃焼によって生成する $\mathrm{CO}_{2}$ が求まる。コー クス配合量打よびコークスに含有される固定炭素濃度から 原料層中の固定炭素量が判り，コークス燃焼由来の $\mathrm{CO}$ 打 よび $\mathrm{CO}_{2}$ も判るので, 焼結後の未燃炭素量が求まる。本実 験では, 出側ガス量を連続分析しているので, 粉コークス の完全燃焼 $\left(\mathrm{C}+\mathrm{O}_{2} \rightarrow \mathrm{CO}_{2}\right)$, 不完全燃焼 $\left(\mathrm{C}+1 / 2 \mathrm{O}_{2} \rightarrow \mathrm{CO}\right)$ および未燃の各量が求まる。ここで, 完全燃焼および不完 全燃焼における発熱量 ${ }^{13)}$ は下記式の通り, $408 \mathrm{~J} / \mathrm{mol}$ および $125 \mathrm{~J} / \mathrm{mol}$ である。本論文では，コークス燃焼に関するパラ メータとして，1）コークス燃焼効率は全固定炭素が完全燃 焼した際に得られる熱量に対する比率，2）コークス燃焼熱 はコークス燃焼効率を考慮した值とした。

Table 2. Increasing heat generation of coke combustion and magnetite oxidation by use of separating granulation method.

Coke combustion (A)

\begin{tabular}{c|c|c|c|c|c|c}
\hline \multirow{2}{*}{} & \multicolumn{4}{|c|}{ Constitue of exhaust gas } & \multicolumn{2}{c}{ Combustion (MJ/t) } \\
\cline { 2 - 7 } & $\mathrm{CO}$ & $\mathrm{CO}_{2}$ & $\mathrm{CO}+\mathrm{CO}_{2}$ & Unburnt & \multicolumn{2}{c}{ [difference] } \\
\hline $0 \mathrm{~A}$ & $10.1 \%$ & $83.5 \%$ & $93.6 \%$ & $6.4 \%$ & 1236.9 & - \\
\hline 1 & $11.6 \%$ & $85.2 \%$ & $96.7 \%$ & $3.3 \%$ & 1266.7 & 29.9 \\
\hline 2 & $10.7 \%$ & $84.4 \%$ & $95.1 \%$ & $4.9 \%$ & 1251.7 & 14.8 \\
\hline
\end{tabular}

Magnetite oxidation (B)

\begin{tabular}{c|c|c|c}
\hline \multirow{2}{*}{} & \multicolumn{2}{|c|}{$\mathrm{FeO}$ in sinter } & Oxidation $(\mathrm{MJ} / \mathrm{t})$ \\
\cline { 2 - 4 } & & difference & difference \\
\hline 0A & 9.5 & - & - \\
\hline 1 & 8.3 & -1.2 & 17.0 \\
\hline 2 & 7.4 & -2.2 & 29.8 \\
\hline
\end{tabular}

Heat generation $(\mathrm{A}+\mathrm{B})$

\begin{tabular}{c|c}
\hline \multicolumn{2}{c}{ Heat generation $(\mathrm{MJ} / \mathrm{t})$} \\
\hline & difference \\
\hline 1236.9 & - \\
\hline 1283.7 & 46.9 \\
\hline 1281.5 & 44.7 \\
\hline
\end{tabular}

$\mathrm{C}+\mathrm{O}_{2}=\mathrm{CO}_{2}+408 \mathrm{~kJ} / \mathrm{mol}$ : 完全燃焼

$\mathrm{C}+1 / 2 \cdot \mathrm{O}_{2}=\mathrm{CO}+125 \mathrm{~kJ} / \mathrm{mol}$ : 不完全燃焼

一方, マグネタイトからへマタイトへの酸化熱 ${ }^{13)}$ は下記 式の通り，マグネタイト1モルあたり $115 \mathrm{~kJ} / \mathrm{mol}$ であたえ た。

$\mathrm{Fe}_{3} \mathrm{O}_{4}+1 / 4 \mathrm{O}_{2}=3 / 2 \mathrm{Fe}_{2} \mathrm{O}_{3}+115 \mathrm{~kJ} / \mathrm{mol}$

マグネタイトからへマタイトへの酸化熱については, 焼 結鉱 $\mathrm{FeO}$ 值からは熱量の絶対值を算出するのが難しい。そ れは，上記マグネタイトの酸素による酸化反応の他, $\mathrm{CO}$, $\mathrm{CO}_{2}$ が関与する酸化還元反応も考慮する必要があるためで ある。そのため, 本検討においては, 実験ケース間の熱量 差なる相対評価した。即ち, 焼結鉱 $\mathrm{FeO}$ 濃度差 $\Delta \mathrm{FeO}$ をマ グネタイトからへマタイトへの酸素による酸化反応差と仮 定した。Table 2 に, 粉コークス燃焼熱打よびマグネタイト 酸化熱を比較する。一括造粒と比較して, 分割造粒を採用 したケースは, 粉コークスの燃焼効率が向上した。熱量換 算すると, 配合原料 $1 \mathrm{t}$ あたり 15〜30 MJの増熱であるが, この值は, 粉コークス燃焼熱量全体に対して, $1.2 \sim 2.4 \% に$ 相当する。一方, 成品 $\mathrm{FeO}$ が低減した分, マグネタイトか らへマタイトへの酸化熱を享受した。この増熱は配合原料 $1 \mathrm{t}$ あたり 17〜30 MJであった。即ち, 分割造粒の採用によ り, 粉コークスの燃焼性向上打よびマグネタイト酸化促進 の双方の効果で, 配合原料 $1 \mathrm{t}$ あたりの増熱が $45 \sim 47 \mathrm{MJ}$ と 評価された。この増熱により，高温保持時間が伸延したも のと考えられる。

\section{$5 \cdot 3$ 焼結層流通ガス顕熱}

ガス顕熱は, 流通ガス量, ガス密度, ガス比熱, ガス温 度の積である。ここで, 流通ガス量は, 鍋試験装置出側以 降の排ガス配管オリフィスで計測した排ガス量とした。但 し，焼結層を流通するガスがオリフィスを通過するまで 2 秒要するので，この時間差を考慮した。ガス密度は排ガス 温度に打ける密度值とした。留るガス比熱はガス組成と温 度に依存するが, ガス組成は焼結層へ捜入した熱電対の計 測情報を採用した。顕熱計算におけるガス温度は焼結層上 部入側ガス温度を基準とした差異とした。従って，上層に おける入側ガス顕熱量は 0 となる。Table 3 に, 各ケース層 高方向 3 層に打ける入側ガス顕熱打よび出側ガス顕熱を 示す。入側ガス顕熱は, 上層で 0 , 中下層は, 上部の高温ガ

Table 3. Gas sensible heat at each vertical position.

\begin{tabular}{|c|c|c|c|c|c|c|}
\hline \multirow{4}{*}{$\begin{array}{l}\text { Integlation period } \\
\text { Inlet and outlet } \\
\text { position }\end{array}$} & \multicolumn{6}{|c|}{ Gas sensible heat $(\mathrm{MJ} / \mathrm{t})$} \\
\hline & \multicolumn{2}{|c|}{ Flame front in upper zone } & \multicolumn{2}{|c|}{ Flame front in middle zone } & \multicolumn{2}{|c|}{ Flame front in bottom zone } \\
\hline & inlet & outlet & inlet & outlet & inlet & outlet \\
\hline & surface & (a) in Fig. 14 & (a) in Fig. 14 & (b) in Fig. 14 & (b) in Fig. 14 & (c) in Fig.14 \\
\hline $0 \mathrm{~A}$ & 0 & 24 & 642 & 93 & 617 & 23 \\
\hline 1 & 0 & 20 & 680 & 32 & 690 & 24 \\
\hline 2 & 0 & 23 & 698 & 30 & 577 & 26 \\
\hline
\end{tabular}


Table 4. Heat consumption at each vertical position.

\begin{tabular}{c|c|c|c|c}
\hline \multirow{2}{*}{} & \multicolumn{4}{|c}{ Heat consumption in sintering bed (MJ/t) } \\
\cline { 2 - 5 } & Upper & Middle & Bottom & Average \\
\hline 0A & 1213 & 1786 & 1831 & 1610 \\
\hline 1 & 1264 & 1932 & 1950 & 1715 \\
\hline 2 & 1259 & 1950 & 1832 & 1680 \\
\hline
\end{tabular}

スが供給されるので $600 \mathrm{MJ} / \mathrm{t}$ 程度の值となる。一方, 出側 ガス顕熱は，上中下層いずれも $60-70^{\circ} \mathrm{C}$ 程度のため, 20-30 $\mathrm{MJ} / \mathrm{t}$ 程度の值となる。

\section{$5 \cdot 4$ 焼結層消費熱量}

Table 4 に消費熱量試算結果を示す。上層と比較して, 中 下層で $600 \mathrm{MJ} / \mathrm{t}$ 程度高かった。これは, 焼結層入側ガス顕 熱の差である。次にケース間の比較では, 上層および中層 では，一括造粒のケース $0 \mathrm{~A} に$ 対して，分割造粒を採用した ケース 1 , さらに, マグネタイト微粉鉱石と高 $\mathrm{Al}_{2} \mathrm{O}_{3}$ ヘマタ イト鉱石を同一造粒系で处理したケース 2 に打いて, 焼結 層の上中下層いずれの層でも高くなった。下層では, ケー ス $0 \mathrm{~A}$ に対して，ケース $1 て ゙$ 高くなりケース 2 は同等であっ た。ケース $0 \mathrm{~A} に$ 対するケース 1 の消費熱量増加量は，上層 $50 \mathrm{MJ} / \mathrm{t}$ に対して, 中層 $150 \mathrm{MJ} / \mathrm{t}$, 下層 $120 \mathrm{MJ} / \mathrm{t}$ と高い。これ は，上層から中層へのガス顕熱供給増加および中層から下 層へのガス顕熱供給増加の影響である。

以上の本検討結果抢よび考察を踏まえ, 焼結鉱の泠間強 度および被還元性改善要因を Fig.15に総括する。

マグネタイト鉱石を $\mathrm{CaO}$ 源である石灰石から遠隔配置 し，高 $\mathrm{Al}_{2} \mathrm{O}_{3}$ 鉱石と近接配置すべく，マグネタイト鉱石と 高 $\mathrm{Al}_{2} \mathrm{O}_{3}$ 鉱石および造粒に必要最小限の生石灰を別系統で 造粒する分割造粒法を採用すると，溶融反応が抑制され， マグネタイトが酸化促進される。この酸化促進により, 焼 結鉱中のへマタイト比率の上昇とマグネタイト比率の低下 が確認され，被還元性が向上した。一方，マグネタイト鉱 石の酸化促進は, 焼結層の高温保持時間を上昇せしめ, 冷 間強度向上に結び付く。ここで, 溶融抑制は, 焼結鉱組織 において, 気孔統合の抑制, 鉱物の微細化, 低円形度で示 された。

\section{6. 結言}

本研究では, マグネタイト鉱石配合に打ける焼結鉱被還 元性打よび冷間強度の双方の改善を目的として, マグネタ イト鉱石と高 $\mathrm{Al}_{2} \mathrm{O}_{3}$ 鉱石拉よび造粒に必要最小限の生石灰 を別系統で造粒する分割造粒法の効果を焼結鍋試験で評価 し, 以下の知見が得られた。

（1）上記配合による分割造粒を採用すると，焼結鉱中 $\mathrm{FeO}$ が低下し，焼結鉱被還元性および冷間強度の双方が向 上した。

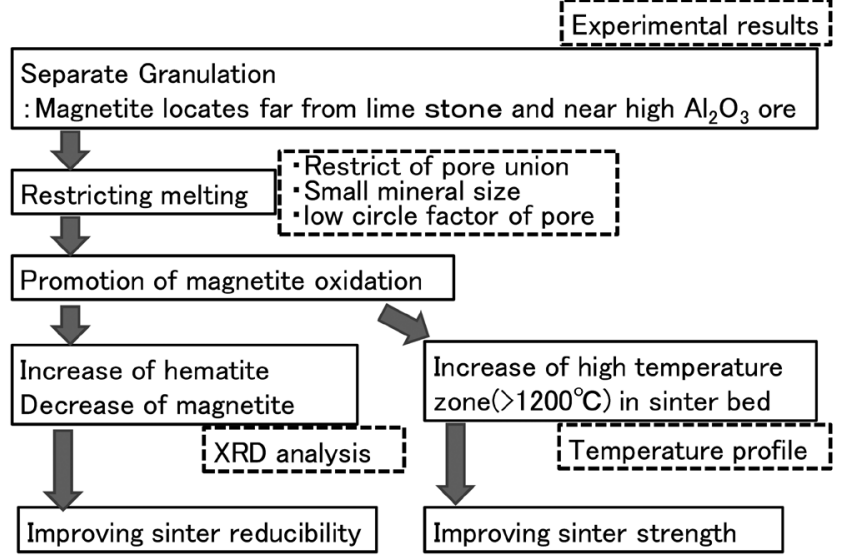

Fig. 15. Mechanism of promoting magnetite ore oxidation and Improving sinter strength and reducibility.

（2）焼結鉱組織より，気孔統合抑制，気孔低円形度，鉱物微 細化が確認された。これは, 焼結反応時の溶融抑制を 傍証するものと考える。

（3）焼結鉱鉱物中のマグネタイト減少打よびへマタイト上 昇が確認された。この結果は上記（1）の $\mathrm{FeO}$ 低下と対 応する。

（4）上記 (1)～(3) より, 本分割造粒法により, 溶融反応抑 制がマグネタイト鉱石酸化を促進し，その結果，焼結 鉱被還元性および冷間強度の改善に結び付いたと考え られる。

\section{文献}

1 ) T.Maeda and Y.Ono: Tetsu-to-Hagané, 72(1986), 775.

2 ) K.Fujino, T.Murakami and E.Kasai: CAMP-ISIJ, 29(2016), 7, CDROM.

3 ) H.Ohgi, K.Ohno, T.Maeda and K.Kunitomo: CAMP-ISIJ, 29(2016), 5, CD-ROM.

4 ) M.Hayashi, Y.Katahira and T.Watanabe: CAMP-ISIJ, 29(2016), 11, CD-ROM.

5 ) T.Kawaguchi, K.Kuriyama, S.Sato and K.Takata: Tetsu-to-Hagané, 76(1990), 1642.

6 ) T.Haga, A.Ohshio, Y.Hida, H.Fukuda and N.Ogata: Tetsu-to-Hagané, 83(1997), 233.

7 )Y.Hosotani, N.Konno, S.Kabuto, M.Kitamura and T.Abe: Tetsu-toHagané, 83(1997), 347.

8 ) T.Kawaguchi, S.Kasama and T.Inazumi: Tetsu-to-Hagané, 78(1992), 1053.

9 ) T.Matsumura, K.Morioka, M.Shimizu, T.Noda and T.Matsuo: Tetsuto-Hagané, 82(1996), 23.

10) S.Machida, K.Nushiro, K.Ichikawa, H.Noda and H.Sakai: Tetsu-toHagané, 92(2006), 755.

11) M.Hoshi, M.Matsumura and T.Kawaguchi: CAMP-ISIJ, 18(2005), 22.

12) H.M.Rietveld: J .Appl. Crystallogr., 2, 65(1969), 1012.

13）高炉製銑法の基礎理論, 盛利貞, 藤村侯夫, 小島康訳, ドイツ 鉄鋼協会編，アグネ，東京，(1979), 10. 